\title{
KEMAMPUAN PELAFALAN BUNYI KOSAKATA DASAR BAHASA INDONESIA OLEH LUTSIANA ANAK TUNAGRAHITA RINGAN DI SLB NEGERI PATRANG KABUPATEN JEMBER
}

\section{RECITATION ABILITY OF BASIC VOCABULARY SOUNDS IN INDONESIAN ON LUTSIANA CHILDREN WITH MILD MENTAL RETARDATION IN SLB NEGERI PATRANG, JEMBER REGENCY}

\author{
Nenes Mardiati ${ }^{1}$, Asrumi $^{2 *}$, Budi Suyanto ${ }^{3}$ \\ ${ }^{1}$ Alumnus Fakultas Ilmu Budaya, Universitas Jember \\ ${ }^{2,3}$ Fakultas Ilmu Budaya, Universitas Jember \\ *Corresponding Author: asrumi.sastra@unej.ac.id \\ Informasi Artikel: \\ Dikirim: 28/2/2018; Direvisi: 23/3/2018; Diterima: 5/4/2018
}

\begin{abstract}
The study aims to describe the forms of basic vocabulary sound pronunciation and the factors that influence the side of mild mental retardation children are not able to pronounce the sounds of the language. Data in the form of pronunciation of speech sounds on the basic vocabulary of Indonesian language sourced from Sisi with mild mental retardation children were collected by observation method with fishing, recording, and recording techniques. The data in the form of information about the factors behind them are from parents and the teacher is collected by using in-depth interviewing with recording and recording techniques. The data that has been classified is analyzed by phonetic articulatory matching method and qualitative descriptive method. The results show that the pronunciation of Sisi in pronouncing vowels and diphthongs can be said to be influenced by the Javanese language, because Sisi's parents are Javanese. On the pronunciation of the consonant sound, Sisi experiences an inability to recite. The inability of the Side to pronounce consonant sounds is influenced by health factors. The sides experience language brain damage which results in a communication process disturbance, coupled with the Sisi speech tool condition which is a slightly larger and thicker tongue which has an impact on the production of the language sounds produced and results in phonetic disturbances.
\end{abstract}

Keywords: basic vocabulary, mental retardation, pronunciation ability, psycholinguistics

Abstrak

Penelitian bertujuan mendeskripsikan bentuk-bentuk pelafalan bunyi kosa kata dasar dan faktor-faktor yang mempengaruhi Sisi anak tunagrahita ringan tidak mampu melafalkan bunyi-bunyi bahasa tersebut. Data yang berupa kemampuan pelafalan bunyi-bunyi ujaran pada kosa kata dasar bahasa Indonesia bersumber dari Sisi anak tunagrahita ringan dikumpulkan dengan metode observasi dengan teknik pancing, catat, 


\begin{abstract}
dan rekam. Data yang berupa informasi tentang faktor-faktor yang melatarbelakanginya bersumber dari orang tua dan gurunya dikumpulkan dengan metode wawancara mendalam (indepth interviewing) dengan teknik catat dan rekam. Data yang telah diklasifikasi dianalisis dengan metode padan fonetis artikulatoris dan metode deskriptif kualitatif. Hasilnya menunjukkan bahwa pelafalan Sisi dalam melafalkan bunyi vokal dan diftong dapat dikatakan dipengaruhi oleh bahasa Jawa, karena orang tua Sisi merupakan orang Jawa. Pada pelafalan bunyi konsonan, Sisi mengalami ketidakmampuan dalam pelafalannya. Ketidakmampuan Sisi dalam melafalkan bunyi konsonan dipengaruhi oleh faktor kesehatan. Sisi mengalami kerusakan otak bahasa yang mengakibatkan gangguan proses komunikasi, ditambah dengan kondisi alat wicara Sisi yaitu lidahnya yang sedikit lebih besar dan tebal sehingga berdampak pada produksi bunyi-bunyi bahasa yang dihasilkannya dan mengakibatkan terjadinya gangguan fonetik.
\end{abstract}

Kata kunci: kosakata dasar, tunagrahita, kemampuan pelafalan, psikolinguistik

\title{
PENDAHULUAN
}

Bahasa memiliki peran penting dalam kehidupan manusia karena digunakan untuk berbahasa. Bahasa dan berbahasa merupakan dua hal yang berbeda. Bahasa adalah alat yang digunakan untuk berkomunikasi, sedangkan berbahasa adalah proses menyampaikan informasi. Peranan bahasa sangat besar dalam proses berpikir seseorang. Pada hakikatnya manusia tidak dapat berpikir tanpa bahasa, karena bahasa merupakan alat berpikir yang utama. Bahasa digunakan manusia untuk melahirkan segala macam pengertian, ide, konsep, dan pikiran. Oleh karena itu, dari bahasa yang digunakan dapat diketahui cara berpikir dan keluwesan pikiran seseorang. Manusia dalam berbahasa akan mengeluarkan atau menghasilkan bunyi-bunyi yang ditangkap oleh telinga kemudian diproses melalui otak sehingga manusia tersebut dapat mengerti pembicaraan lawan bicaranya. Bunyi bahasa yang dihasilkan tentu berbeda dengan bunyi-bunyi yang lain, misalnya bersiul atau mendengkur. Bunyi bahasa yang dapat dimengerti, menandakan bahwa pembicara memiliki bahasa yang sama dengan lawan bicara. Sebaliknya, jika seseorang mendengar urutan bunyi bahasa tetapi tidak mengerti apa yang dikatakan oleh lawan bicaranya, itu berarti bahasa yang digunakan oleh lawan bicara terdengar asing oleh seseorang tersebut (Pateda, 1990:27).

Pengolahan bahasa dalam proses berpikir manusia terjadi pada organ tubuh yang disebut otak. Otak merupakan pusat sistem syaraf dan berfungsi untuk mengendalikan tubuh manusia. Otak manusia tersebut dibagi menjadi dua bagian, yaitu otak kanan dan otak kiri. Otak sebelah kiri manusia berfungsi untuk berbahasa atau mengolah bahasa. Chomsky dan Miller (dalam Chaer, 2009:169) mengatakan bahwa ada alat khusus di dalam otak manusia yang dimiliki setiap anak sejak lahir untuk dapat berbahasa. Alat khusus di dalam otak manusia itu dinamakan language acquisition device (LAD), yang memungkinkan seorang anak memperoleh bahasa ibunya. Menurut Chaer (2003:148) manusia yang normal memiliki otak bahasa dan alat bicara yang berfungsi dengan baik 
akan dapat berbahasa dengan baik pula, namun mereka yang otak dan alat bicaranya memiliki kelainan fungsi, seperti seseorang yang memiliki gangguan psikis atau seseorang dengan bibir sumbing (cacat fisik) akan kesulitan dalam berbahasa.

Otak bahasa manusia terdapat bagian yang disebut dengan Broca dan Wernicke. Chaer (2009:122) menyatakan bahwa kerusakan pada daerah Broca menyebabkan seseorang mendapatkan kesulitan dalam menghasilkan ujaran, sedangkan Wernicke berperan penting dalam pemahaman ujaran. Maksudnya, jika bagian Wernicke rusak, maksud pembicaraannya tidak dimengerti orang lain. Kerusakan kedua bagian otak tersebut pada anak menyebabkan anak mengalami kesulitan dalam proses komunikasi yang berdampak pada kemampuan pelafalan bahasa. Kemampuan berbahasa seseorang atau anak dapat dilihat dari kemampuan melafalkan kosakata karena bahasa merupakan alat penyalur pemikiran (Tarigan, 1993:2). Jika seseorang mengalami gangguan pada otak bahasa akan menyebabkan keterampilan pelafalan kosakata tidak tepat, ia tidak dapat mengungkapkan pemikirannya secara tepat pada lawan bicaranya. Menurut Chaer (2003:148) penyebab gangguan proses komunikasi dibagi menjadi dua garis besar. Pertama, gangguan yang disebabkan oleh faktor medis, yaitu gangguan karena fungsi otak dan kelainan alat bicara. Kedua, disebabkan oleh faktor lingkungan sosial, seperti tersisih atau terisolasi dari lingkungan kehidupan masyarakat. Salah satu gangguan yang disebabkan oleh faktor medis atau gangguan fungsi otak disebut tunagrahita.

Tunagrahita adalah suatu kondisi yang hadir sejak masa kanak-kanak, dicirikan dengan fungsi intelektual umum yang secara signifikan berada di bawah rata-rata atau memiliki IQ 70 ke bawah (Halgin dan Whitbourne, 2010:126). Anak tunagrahita memiliki kelemahan dalam beberapa hal, termasuk beradaptasi dengan orang lain dalam kehidupan sehari-hari. Misalnya, mereka kurang dalam hal keterampilan sosial, tidak dapat merawat diri mereka sendiri, dan memiliki kesulitan dalam berkomunikasi atau berbahasa. Anak tunagrahita memiliki perkembangan bahasa yang berbeda dengan perkembangan bahasa teman sebayanya yang tidak tunagrahita. Pembahasan mengenai perkembangan bahasa ujaran dan hubungannya dengan anak tunagrahita di dalam kajian psikolinguistik (Puspitasari, 2012; Angwidya, 2017; Muryani 2017) mendeskripsikan bahwa anak tunagrahita kesulitan dalam mengartikulasi kosakata bahasa Indonesia. Kapasitas belajar anak tunagrahita terutama yang bersifat abstrak seperti belajar dan berhitung, menulis, dan membaca juga terbatas. Kesulitan dalam berkomunikasi pada anak tunagrahita juga dapat dikatakan sebagai gangguan berbahasa atau afasia. Anak dengan gangguan bahasa atau afasia tidak memiliki kemampuan untuk mengekspresikan diri mereka dengan cara yang sesuai dengan kelompok usia mereka. Hal tersebut dapat terlihat jelas pada gaya bahasa termasuk dalam penggunaan kosakata yang terbatas dan tidak tepat serta berbicara dalam kalimat yang singkat (Halgin dan Whitbourne, 2010:150).

Pada umumnya seseorang dengan tunagrahita dapat dijumpai di berbagai kalangan masyarakat, namun banyak orang yang tidak menyadari hal tersebut. Penyandang tunagrahita dapat dengan mudah dijumpai di Sekolah Luar Biasa (SLB), karena dalam belajar mereka membutuhkan perlakuan yang lebih istimewa dibandingkan anak di usia 
sekolah yang tidak memiliki gangguan fungsi otak bahasa. Salah satu SLB di Jember yang mendidik penyandang tunagrahita ialah SLB Negeri Patrang, dengan siswa sebanyak 21 siswa (15 siswa SMP dan 9 siswa SMA). Peneliti berusaha untuk mengamati dan berkomunikasi secara langsung dengan siswa tunagrahita di sekolah tersebut. Hampir semua siswa tunagrahita mampu berbicara mendekati orang normal, namun ada satu siswa yang kemampuan berbicaranya lebih rendah dibandingkan teman-teman tunagrahita lainnya di sekolah tersebut.

Siswa dengan kemampuan berbicara lebih rendah itu berada di kelas 3 SMA, bernama Lutsiyana Eka Ayuningtyas atau yang biasa dipanggil Sisi dengan usia 19 tahun. Menurut informasi dari orang tua Sisi yang telah memeriksakan Sisi pada psikolog di RSU dr. Soebandi Jember, ia merupakan anak tunagrahita ringan dengan IQ 60. Hal ini membuktikan bahwa Sisi termasuk kelompok anak tunagrahita ringan. Pada usia remaja biasanya anak tunagrahita dapat mempelajari keterampilan akademik yang kuranglebih sama dengan level kelas 6 (Davison, Neale, dan Kring, 2006:708). Pada usia 19 tahun seorang anak berada pada taraf remaja, dengan kata lain seharusnya sudah dapat berbicara dengan lancar dan dapat melafalkan kosakata bahasa Indonesia dengan baik.

Pada pengamatan awal, peneliti meminta Sisi untuk menyebutkan benda-benda di sekitar yang berkaitan dengan kosakata bahasa Indonesia, kemudian peneliti merekam dan mencatat kosakata yang dilafalkan tersebut. Asumsi awal pengamatan menjelaskan bahwa ketika Sisi melafalkan bunyi-bunyi bahasa tertentu mengalami kesulitan. Bentuk asumsi tersebut kemudian diuji kembali dengan mengumpulkan kosakata dasar bahasa Indonesia. Fenomena kebahasaan yang ditunjukkan oleh Sisi adalah mengalami kesulitan dalam mengartikulasikan bunyi bahasa dengan benar. Contoh beberapa kosakata dasar yang dilafalkan oleh Sisi sebagai berikut.

\begin{tabular}{|l|l|l|}
\hline Jayi & gunun & selebar \\
\hline [jayi] & [gunUn] & {$[$ sələbar] } \\
\hline 'jari' & 'gunung' & 'selembar' \\
\hline
\end{tabular}

Dari data di atas, terlihat bahwa Sisi mengalami gangguan dalam pelafalan kosakata yang dituturkannya. Pada kata jari [jari] terjadi penggantian bunyi konsonan [r] menjadi [y] sehingga pelafalannya mmenjadi jayi [jayi]. Kata gunung [gunuy] juga mengalami penggantian bunyi konsonan yaitu bunyi $[\mathrm{y}]$ menjadi bunyi [n] sehingga pelafalannya menjadi gunun [gunUn], dan pada kata selembar [sələmbar] terjadi penghilangan bunyi [m] sehingga pelafalannya menjadi selebar [sələbar]. Uraian- uraian pelafalan bunyi tersebut dapat diketahui bahwa Sisi masih belum mampu melafalkan kosakata bahasa Indonesia dengan benar, khususnya pada kosakata dasar bahasa Indonesia. Uniknya tidak semua bunyi [r] berubah menjadi bunyi [y] dan tidak semua bunyi [m] pada kata-kata lain selalu hilang. 
Fenomena kemampuan pelafalan bunyi-bunyi kebahasaan yang ditunjukkan oleh Sisi tersebut telah mendorong minat peneliti untuk melakukan penelitian tentang kemampuan pelafalan bunyi-bunyi bahasa dalam kosakata dasar bahasa Indonesia pada anak tunagrahita ringan dengan satu subjek penelitian atau studi kasus. Tujuan penelitian ini mendeskripsikan kemampuan pelafalan bunyi-bunyi bahasa Indonesia meliputi bunyi vokal, diftong, dan konsonan oleh Sisi anak tunagrahita ringan, sehingga dapat diketahui faktor yang mempengaruhi terjadinya kesulitan pelafalan bunyi bahasa. Kosakata dasar tersebut meliputi kata-kata anggota tubuh, kata ganti, kata-kata yang menyatakan perasaan, kata-kata yang berkaitan dengan cuaca dan alam, kata bilangan, dan kata-kata benda yang berhubungan dengan perlengkapan rumah tangga dan dianggap ada sejak permulaan atau sejak dahulu (Keraf, 1984:114). Kosakata dasar dipilih karena menggambarkan kata-kata yang ada di kehidupan sehari- hari, yang diketahui baik oleh anak normal maupun anak yang memiliki gangguan pada otaknya sehingga Sisi tidak terlalu kesulitan dalam menyebutkan kosakata yang diinginkan peneliti.

Beradasarkan ruang lingkup yang dikemukakan di atas, permasalahan yang akan dikaji dalam penelitian ini sebagai berikut. 1) Bagaimana kemampuan Sisi anak tunagrahita ringan dalam melafalkan bunyi-bunyi kosa kata dasar bahasa Indonesia? 2) Faktor-faktor apakah yang mempengaruhi terjadinya kesulitan pelafalan bunyi-bunyi kosa kata dasar bahasa Indonesia tersebut?

\section{METODE}

Metode merupakan cara memahami dan memecahkan masalah dalam penelitian. Dalam penanganan tahap analisis data diperlukan metode dan teknik-teknik yang cukup andal (Mahsun, 2016:111). Menurut Sudaryanto (2015:9), metode dan teknik merupakan dua konsep yang berbeda tetapi berhubungan langsung satu dengan yang lain. Keduanya adalah cara dalam suatu upaya penelitian. Metode adalah cara yang harus dilaksanakan atau diterapkan, sedangkan teknik adalah cara melaksanakan atau menerapkan metode. Penelitian ini dapat dikategorikan sebagai penelitian kualitatif, yaitu salah satu metode penelitian yang teknik analisisnya menghasilkan data deskriptif berupa kata-kata tertulis atau lisan. Penelitian ini dilakukan dengan mengamati langsung subjek penelitian yang biasa disebut observasi.

Dalam penyediaan data tentang kemampuan pelafalan kosakata dasar oleh anak tunagrahita ringan, peneliti menggunakan metode simak atau penyimakan. Metode simak juga dapat disejajarkan dengan metode pengamatan dan observasi dalam bidang sosial. Sudaryanto (1993:133) menyatakan, disebut metode simak karena dalam pengambilan data dilakukan penyimakan terhadap pelafalan bahasa oleh subjek peneltian. Metode simak ini digunakan untuk memperoleh data berupa kemampuan pelafalan kosakata oleh anak tunagrahita ringan dengan teknik sadap, rekam, dan catat. Dalam hal ini, peneliti mengamati pelafalan kosakata subjek penelitian dengan meminta subjek penelitian meniru untuk melafalkan beberapa kosakata dasar dalam bahasa Indonesia. Kosakata dasar tersebut merupakan kata yang berhubungan dengan anggota tubuh, kata ganti, kata yang 
menyatakan perasaan, kata yang berkaitan dengan cuaca dan alam, kata bilangan, dan kata benda yang berhubungan dengan perlengkapan rumah tangga.

Data tentang faktor-faktor yang melatarbelakangi ketidakmampuan pelafalan bunyibunyi kosakata dasar bahasa Indonesia pada Sisi, anak tunagrahita yang diperoleh dari guru dan orang tua menggunakan metode wawancara mendalam (indepth interviewing) atau kerja sama dengan subjek penelitian (Subroto, 1992) dengan teknik catat dan rekam. Data yang telah dikumpulkan kemudian diklasifikasi berdasarkan kemampuan pengucapan kosakata dasar yang berupa vokal dan konsonan.

Data kemampuan pelafalan bunyi-bunyi kosakata dasar dalam bahasa Indonesia yang telah diklasifikasi dianalisis dengan metode padan fonetis artikulatoris, yang menjadi penentu dalam metode ini adalah organ wicara. Sudaryanto (2015:28) menyatakan dalam kaitannya dengan pembentukan satuan lingual tertentu (dapat bunyi, dapat silabe, dapat kata, dapat kalimat, dan dapat pula yang lain) akan kelihatan bahwa organ wicara dapat berbeda-beda dalam mengaktifkan bagian-bagiannya. Dari analisis dengan menggunakan metode padan fonetis artikulatoris tersebut akan diketahui bentuk- bentuk kesesuaian ataupun ketidaksesuaian bunyi bahasa, serta memperlihatkan cara-cara artikulasi bunyi yang terjadi pada anak tunagrahita ringan. Hasil analisis tersebut kemudian dianalisis kembali melalui struktur luar bahasa dengan menghubungkan teori-teori yang ada, sehingga dapat diketahui faktor-faktor yang menjadi penyebab terjadinya kesulitan pelafalan pada bunyi bahasa tertentu. Data yang telah dianalisis dan dibahas disajikan dengan metode penyajian secara informal, yakni penyajian dengan menggunakan kata-kata biasa dan metode penyajian secara formal, yakni penyajian dengan menampilkan tanda-tanda dan simbol-simbol fonetis kebahasaan (Sudaryanto, 2015:241). Data tentang faktor-faktor yang melatarbelakangi ketidakmampuan Sisi dalam melafalkan bunyi-bunyi kosakata dasar bahasa Indonesia dianalisis dengan metode deskriptif kualitatif, yakni pemaparan kembali dari hasil wawancara mendalam.

\section{HASIL DAN PEMBAHASAN}

Hasil penelitian kemampuan pelafalan bunyi- bunyi bahasa pada kosakata dasar bahasa Indonesia oleh Sisi anak tunagrahita ringan di SLB Negeri Patrang Kabupaten Jember ini meliputi: (1) bentuk pelafalan bunyi- bunyi bahasa pada kosakata dasar bahasa Indonesia oleh Sisi, (2) faktor-faktor yang mempengaruhi terjadinya kesulitan pelafalan bunyi bahasa Sisi. Untuk lebih jelasnya dapat dilihat pada uraian berikut.

Kemampuan Pelafalan Bunyi-bunyi bahasa pada Kosakata Dasar Bahasa Indonesia oleh Sisi dibedakan atas kemampuan pelafalan bunyi-bunyi vokal, bunyi-bunyi diftong, dan bunyi-bunyi konsonan. Berikut uraiannya.

\section{Kemampuan Pelafalan Bunyi Vokal}

Vokal adalah jenis bunyi bahasa yang ketika dihasilkan atau diproduksi setelah arus ujar dari glotis tidak mendapat hambatan dari alat ucap, melainkan hanya diganggu 
oleh posisi lidah, secara vertikal, horisontal, dan bentuk mulut. Vokal dalam bahasa Indonesia meliputi [a], [i], [u], [e], dan [o]. Dalam penelitian ini, subjek penelitian yang bernama Lutsiyana Eka Ayuningtyas atau yang biasa dipanggil Sisi tidak mengalami kesulitan dalam melafalkan bunyi vokal dan dalam pelafalannya tersebut juga ada pengaruh bahasa Jawa karena ayah dan ibu Sisi merupakan orang Jawa dan lingkungan di sekolahnya juga lebih sering menggunakan bahasa Jawa. Kemampuan pelafalan bunyi vokal oleh Sisi sebagai berikut.

Pada pelafalan vokal [a] oleh Sisi, ada pengaruh bahasa Jawa yaitu dapat dilihat pada kata senang [sənan]. Kata senang [sənay], vokal [a] dengan posisi silabel tertutup (KVK) pelafalannya menjadi [ə], sehingga kata senang [sənay] menjadi seney [sənəџ]. Pengaruh bahasa Jawa bukan hanya terjadi pada pelafalan vokal [a] tetapi juga terdapat pada vokal lain.

Vokal [i] juga terdapat pengaruh bahasa Jawa pada saat Sisi melafalkannya. Hal tersebut dapat dilihat pada kata nasi [nasi] dan kaki [kaki], pelafalan Sisi menjadi nasik [nasi?] dan kakik [kaki?], dalam pelafalan kata tersebut terdapat penambahan bunyi glotal [?]. Vokal [i] tersebut dalam pelafalannya terdapat variasi bunyi yang diakibatkan oleh lingkungan bunyi dalam sebuah kata. Vokal [i] dengan silabe terbuka tetap dilafalkan dengan bunyi [i] tinggi atas, seperti pada data di atas yaitu kata gigi [gigi]. Vokal [i] pada silabe tertutup maka pelafalannya menjadi [I] tinggi bawah, seperti pada kata kulit [kulIt]. Oleh karena itu, dapat dikatakan bahwa dalam pelafalan bunyi [i], Sisi melafalkannya dengan bunyi [i?], tetap [i], dan berupa [i] tinggi.

Vokal [u] sama halnya dengan vokal [i], terdapat variasi bunyi yang diakibatkan oleh lingkungan bunyi dalam sebuah kata. Vokal $[\mathrm{u}]$ dengan silabe terbuka dilafalkan dengn bunyi [u] tinggi atas, seperti pada kata bambu [bambu], paku [paku]. Pada silabe tertutup pelafalannya menjadi nyamuk [ñamU?]. Oleh karena itu, dapat dikatakan bahwa kemampuan Sisi dalam melafalkan vokal [u] dapat berupa [u] dan [U] atau kategori normal.

Bunyi vokal [e] pada kata tempe, sembilan, monyet adalah tidak sama. Berdasarkan tinggi rendahnya posisi lidah bunyi-bunyi, vokal [e] dibedakan menjadi tiga, yaitu vokal [e] sedang atas, vokal [ə] sedang tengah, dan vokal [ $\varepsilon$ ] sedang bawah. Kata tempe pelafalannya yaitu [tempe], kata sembilan pelafalannya yaitu [səmbilan], dan kata monyet pelafalannya menjadi [moñet]. Untuk itu, dapat dikatakan bahwa dalam pelafalan vokal [u], Sisi dikategorikan normal.

Bunyi vokal [o] berdasarkan tinggi rendahnya posisi lidah juga dibedakan menjadi dua, yaitu bunyi vokal [o] sedang atas dan bunyi vokal [o] sedang bawah. Bunyi vokal [o] sedang atas seperti pada kata komodo [komodo], sedangkan bunyi vokal [o] sedang bawah seperti pada kata pohon [pohon] dan kedondong [kədondong]. Hal ini menunjukkan bahwa Sisi berkategori normal dalam pelafalan vokal [o]. 


\section{Kemampuan Pelafalan Bunyi Diftong}

Bunyi diftong berkaitan dengan dua vokal dan yang merupakan satu bunyi dalam satu silabel. Diftong memiliki tiga macam, yaitu diftong naik, diftong turun, dan diftong memusat. Bahasa Indonesia hanya memiliki satu diftong, yaitu diftong naik. Pelafalan bunyi diftong oleh Sisi dapat dilihat pada uraian berikut.

\begin{tabular}{|l|l|l|}
\hline $\begin{array}{l}\text { Kosakata Bahasa } \\
\text { Indonesia }\end{array}$ & Pelafalan Sisi & $\begin{array}{l}\text { Bentuk } \\
\text { Perubahan }\end{array}$ \\
\hline $\begin{array}{l}\text { Cabai } \\
\text { [cabay] }\end{array}$ & $\begin{array}{l}\text { Cabe } \\
\text { [cabe] }\end{array}$ & ai -e \\
\hline $\begin{array}{l}\text { Pisau } \\
\text { [pisaw] }\end{array}$ & $\begin{array}{l}\text { Piso } \\
\text { [piso] }\end{array}$ & au -o \\
\hline
\end{tabular}

Pada data pelafalan bunyi diftong oleh Sisi di atas dapat dikatakan bahwa terdapat proses monoftongisasi. Monoftongisasi adalah proses perubahan dua buah vokal atau gugus vokal menjadi sebuah vokal, yakni bunyi [ai] menjadi [e] dan bunyi [au] menjadi [o]. Proses ini banyak terjadi dalam bahasa Indonesia akibat dari ingin memudahkan ucapan. Untuk itu, dapat dikatakan bahwa kemampuan Sisi dalam pelafalan diftong tergolong normal.

\section{Kemampuan Pelafalan Bunyi Konsonan}

Konsonan adalah bunyi bahasa yang diproduksi dengan cara setelah arus ujar keluar dari glottis mendapat hambatan pada alat-alat ucap tertentu di dalam rongga mulut atau rongga hidung. Bunyi disebut konsonan, bila terjadinya dibentuk dengan menghambat arus udara pada sebagian alat bicara, jadi ada artikulasi. Proses hambatan atau artikulasi ini dapat disertai dengan bergetarnya pita suara. Jika hal ini terjadi yang terbentuk adalah bunyi konsonan bersuara. Jika artikulasi ini tidak disertai dengan bergetarnya pita suara dan glotis dalam keadaan terbuka, bunyi yang dihasilkan adalah konsonan tak bersuara. Analisis bunyi konsonan dibedakan berdasarkan silabe terbuka dengan pola KV (Konsonan Vokal) dan silabe tertutup dengan pola KVK (Konsonan Vokal Konsonan). Untuk lebih jelasnya dapat dilihat pada uraian berikut.

\section{Pelafalan Bunyi Konsonan [b]}

Pada data pelafalan konsonan [b], hampir semua kata mampu Sisi lafalkan dengan benar seperti orang normal. Ada satu kata Sisi mengalami kesulitan dalam melafalkannya, seperti pada uraian berikut.

\begin{tabular}{|l|l|l|}
\hline $\begin{array}{l}\text { Kosakata Bahasa } \\
\text { Indonesia }\end{array}$ & Pelafalan Sisi & $\begin{array}{l}\text { Bentuk } \\
\text { Perubahan }\end{array}$ \\
\hline $\begin{array}{l}\text { Belimbing } \\
\text { [bolimbin] }\end{array}$ & $\begin{array}{l}\text { pebimbin } \\
\text { [pəbimbin] }\end{array}$ & $\mathrm{b}-\mathrm{p}$ \\
\hline
\end{tabular}

Kata belimbing [bəlimbin] memiliki tiga selabe yaitu [bə], [lim], dan [bin], pada silabe pertama [bə] mengalami penggantian bunyi [b] menjadi [p], sehingga kata yang dilafalkan Sisi menjadi pebimbin [pəbimbin]. Bunyi [b] dan bunyi [p] merupakan konsonan hambat letup bilabial yang terjadi bila penghambat artikulator aktifnya adalah bibir bawah 
dan artikulator pasifnya adalah bibir atas. Dalam pelafalan Sisi terjadi kekeliruan dalam letupan udara yang keluar dari rongga mulut. Bunyi yang dihasilkan seharusnya konsonan [b] lunak bersuara namun yang dilafalkan Sisi adalah konsonan [p] keras tak bersuara.

\section{Pelafalan Bunyi Konsonan [c]}

Pelafalan konsonan [c] oleh Sisi tidak mengalami kesulitan dalam pelafalannya sehingga ia dapat melafalkan konsonan [c] pada pola silabel KV atau KVK. Bunyi konsonan [c] termasuk dalam konsonan hambat letup medio-palatal yang terjadi bila artikulator aktifnya adalah tengah lidah dan artikulator pasifnya adalah langit-langit keras.

\section{Pelafalan Bunyi Konsonan [d]}

Dalam melafalkan konsonan [d] ada satu kata yang tidak mampu Sisi lafalkan dengan benar, dapat dilihat pada uraian berikut.

\begin{tabular}{|l|l|l|}
\hline $\begin{array}{l}\text { Kosakata Bahasa } \\
\text { Indonesia }\end{array}$ & Pelafalan Sisi & $\begin{array}{l}\text { Bentuk } \\
\text { Perubahan }\end{array}$ \\
\hline $\begin{array}{l}\text { dua } \\
\text { [duwa] }\end{array}$ & $\begin{array}{l}\text { Uwa } \\
\text { [uwa] }\end{array}$ & $\mathrm{d}$-hilang \\
\hline
\end{tabular}

Proses artikulasi konsonan [d] yaitu ujung lidah sebagai artikulator aktif merapat atau menyentuh ceruk gigi atas yang menjadi artikulator pasifnya, namun cara Sisi mengartikulasikan konsonan [d] adalah tengah lidah sebagai artikulator aktifnya merapat atau menyentuh gigi atas, sehingga menjadi [d] tidak beraspirat. Pada data di atas menunjukkan kata dua [duwa] terjadi penghilangan bunyi konsonan [d] pada saat Sisi melafalkannya, sehingga pelafalannya menjadi [uwa]. Saat proses artikulasi konsonan [d], ujung lidah sebagai artikulator aktif gagal merapat atau menyentuh ceruk gigi atas yang menjadi artikulator pasifnya, sehingga bunyi konsonan [d] tidak dapat dilafalkan.

\section{Pelafalan Bunyi Konsonan [g]}

Pelafalan bunyi konsonan [g] Sisi mengalami beberapa kesulitan dalam pelafalannya. Pelafalan bunyi konsonan [g] pada pola KV, Sisi tidak mengalami kesulitan, namun pada pelafalan konsonan [g] dengan pola KVK ia mengalami kesulitan, seperti pada kata berikut ini.

\begin{tabular}{|l|l|l|}
\hline $\begin{array}{l}\text { Kosakata Bahasa } \\
\text { Indonesia }\end{array}$ & Pelafalan Sisi & $\begin{array}{l}\text { Bentuk } \\
\text { Perubahan }\end{array}$ \\
\hline $\begin{array}{l}\text { Jagung } \\
\text { [jaguy] }\end{array}$ & $\begin{array}{l}\text { Jakul } \\
\text { [jakul] }\end{array}$ & $\mathrm{g}-\mathrm{k}$ \\
\hline $\begin{array}{l}\text { Punggung } \\
\text { [pungun] }\end{array}$ & $\begin{array}{l}\text { Pukul } \\
\text { [pukUl] }\end{array}$ & $\mathrm{g}-\mathrm{k}$ \\
\hline
\end{tabular}

Pada kata jagung [jagun] Sisi mengalami kesulitan dalam melafalkan kata tersebut. Kata jagung [jaguy] memiliki dua silabe yaitu [ja] dan [gun], pada silabe kedua [guy] mengalami penggantian bunyi $[\mathrm{g}]$ menjadi $[\mathrm{k}]$. Dalam pelafalan bunyi tersebut terjadi kekeliruan dalam letupan udara yang keluar dari rongga mulut. Bunyi yang dihasilkan seharusnya konsonan [g] lunak bersuara namun yang dilafalkan Sisi adalah konsonan [k] keras tak bersuara. 
Kata punggung [punguy] sama halnya dengan kata jagung [jaguy], memiliki dua silabel, yaitu [puy] dan [gun]. Pada silabe kedua [guy] mengalami penggantian bunyi [g] menjadi [k]. Pelafalan bunyi Sisi tersebut terjadi kekeliruan dalam letupan udara yang keluar dari rongga mulut. Bunyi yang dihasilkan seharusnya konsonan [g] lunak bersuara namun yang dilafalkan Sisi adalah konsonan [k] keras tak bersuara. Dari kedua data di atas maka dapat dikatakan bahwa Sisi mengalami kesulitan dalam mengatur arus udara, posisi atau gerak lidah yang membentuk bunyi, sehingga terjadilah kekeliruan dalam pelafaan bunyi konsonan $[\mathrm{g}]$ menjadi konsonan $[\mathrm{k}]$. Penggantian bunyi $[\mathrm{g}]$ menjadi $[\mathrm{k}]$ terjadi apabila konsonan $[\mathrm{g}]$ diikuti vokal $[\mathrm{u}]$ kemudian diikuti dengan bunyi [ $\mathrm{g}]$.

\section{Pelafalan Bunyi Konsonan [h]}

Dalam pelafalan bunyi konsonan [h], hampir semua kata dapat Sisi lafalkan dengan benar seperti orang normal, namun ada dua kata yang tidak mampu Sisi lafalkan dengan benar, dapat dilihat pada uraian berikut.

\begin{tabular}{|l|l|l|}
\hline $\begin{array}{l}\text { Kosakata Bahasa } \\
\text { Indonesia }\end{array}$ & Pelafalan Sisi & $\begin{array}{l}\text { Bentuk } \\
\text { Perubahan }\end{array}$ \\
\hline $\begin{array}{l}\text { Hidung } \\
\text { [hiduy] }\end{array}$ & $\begin{array}{l}\text { Idun } \\
\text { [idUn] }\end{array}$ & $\mathrm{h}$-hilang \\
\hline $\begin{array}{l}\text { Perahu } \\
\text { [pərahu] }\end{array}$ & $\begin{array}{l}\text { Prau } \\
\text { [prau] }\end{array}$ & $\mathrm{h}$ - hilang \\
\hline
\end{tabular}

Kata hidung [hidun] memiliki dua silabe, yaitu [hi] dan [dun], namun dalam pelafalan Sisi terjadi penghilangan bunyi [h] pada silabe pertama, sehingga pelafalan kata hidung menjadi idun [idun]. Hal tersebut terjadi karena Sisi tidak mampu mengatur arus udara yang keluar dari paru-paru melewati glotis.

Pada kata perahu [pərahu] memiliki pola silabe KV, dimana V diisi oleh bunyi [ə]. Kata [pərahu] memiliki silabe [pə], [ra], dan [hu], dalam bahasa Jawa sering dilafalkan menjadi [prau], bunyi [ə] dan [h] ditinggalkan. Dari data penghilangan bunyi konsonan [h] pada kata perahu [pərahu] maka dapat dikatakan bahwa pelafalan Sisi dipengaruhi oleh bahasa Jawa, karena orang tua Sisi merupakan orang Jawa.

\section{Pelafalan Bunyi Konsonan [k]}

Bunyi konsonan $[\mathrm{k}]$ merupakan konsonan hambat letup dorso-velar, terjadi bila artikulator aktifnya ialah pangkal lidah dan artikulator pasifnya adalah langit-langit lunak. Bunyi konsonan [k] sebagai konsonan keras tak bersuara. Pelafalan bunyi konsonan [k] pada pola silabel KV maupun KVK, Sisi tidak mengalami kesulitan dalam pelafalannya.

\section{Pelafalan Bunyi Konsonan [l]}

Bunyi konsonan [1] merupakan konsonan sampingan yang dibentuk dengan arus udara di tengah rongga mulut sehingga udara keluar melalui kedua samping. Latera dalam bahasa latin berarti 'samping-samping'. Proses artikulasi konsonan [1] yaitu ujung lidah (apeks) sebagai artikulator aktif merapat atau menyentuh ceruk gigi atas (alveolum) sebagai 
artikulator pasifnya. Pelafalan bunyi konsonan [1] oleh Sisi tempat artikulasinya menjadi tengah lidah sebagai artikulator aktifnya merapat atau menyentuh gigi atas sebagai artikulator pasifnya, Sisi juga mengalami kesulitan pada saat melafalkan kata belimbing [pəbimbIn], untuk lebih jelasnya dapat dilihat pada uraian berikut.

Dalam pelafalan bunyi konsonan [1] Sisi mengalami kesulitan pada saat melafalkan kata belimbing [pəbimbIn], untuk lebih jelasnya dapat dilihat pada uraian berikut.

\begin{tabular}{|l|l|l|}
\hline $\begin{array}{l}\text { Kosakata Bahasa } \\
\text { Indonesia }\end{array}$ & Pelafalan Sisi & $\begin{array}{l}\text { Bentuk } \\
\text { Perubahan }\end{array}$ \\
\hline $\begin{array}{l}\text { Belimbing } \\
{[\text { bolimbin] }}\end{array}$ & $\begin{array}{l}\text { pebimbin } \\
\text { [pəbimbin] }\end{array}$ & $1-\mathrm{b}$ \\
\hline
\end{tabular}

\section{Pelafalan Bunyi Konsonan [m]}

Dari data pelafalan bunyi konsonan [m] oleh Sisi, dapat dideskripsikan bahwa ia hanya mengalami kesulitan pada saat melafalkan kata selembar [sələmbar], uraiannya berikut.

\begin{tabular}{|l|l|l|}
\hline $\begin{array}{l}\text { Kosakata Bahasa } \\
\text { Indonesia }\end{array}$ & Pelafalan Sisi & $\begin{array}{l}\text { Bentuk } \\
\text { Perubahan }\end{array}$ \\
\hline $\begin{array}{l}\text { Sele } m \text { bar } \\
\text { [sələmbar] }\end{array}$ & $\begin{array}{l}\text { Selebar } \\
\text { [sələbar }]\end{array}$ & $\mathrm{m}-$ hilang \\
\hline
\end{tabular}

Kata selembar [sələmbar] memiliki pola silabel KVKdan konsonan [m] sebagai koda. Kata selembar [sələmbar] memiliki tiga silabe, yaitu [sə], [ləm], dan [bar], pada silabe kedua [ləm] terjadi penghilangan bunyi konsonan [m] pada saat Sisi melafalkannya. Pada kata selembar [sələmbar] pelafalan konsonan [m] dengan cara bibir bawah menekan rapat pada bibir atas, sehingga jalannya udara dari paru-paru melalui rongga mulut terhambat dan keluar dari rongga hidung, diikuti konsonan [b] dengan cara artikulasinya bibir bawah menekan bibir atas kemudian secara tiba-tiba dilepaskan, terjadilah letupan dari rongga mulut.

\section{Pelafalan Bunyi Konsonan [n]}

Pelafalan konsonan [n] oleh Sisi mengalami kesulitan ketika melafalkan kata mendung [mənduy], dapat dilihat pada uraian berikut.

\begin{tabular}{|l|l|l|}
\hline $\begin{array}{l}\text { Kosakata Bahasa } \\
\text { Indonesia }\end{array}$ & Pelafalan Sisi & $\begin{array}{l}\text { Bentuk } \\
\text { Perubahan }\end{array}$ \\
\hline $\begin{array}{l}\text { Mendung } \\
\text { [mənduy] }\end{array}$ & $\begin{array}{l}\text { Medun } \\
\text { [mədUn] }\end{array}$ & $\mathrm{n}$-hilang \\
\hline
\end{tabular}

Bunyi konsonan [n] merupakan konsonan nasal apiko-alveolar, terjadi bila penghambat artikulator aktifnya ialah ujung lidah dan artikulator pasifnya ialah ceruk gigi atas, namun Sisi melafalkan konsonan [n] dengan tengah lidah menjadi artikulator aktif mendekati gigi atas yang merupakan artikulator pasif. Data pelafalan konsonan [n] oleh Sisi di atas menunjukkan bahwa hampir semua kata dapat dilafalkan tanpa perubahan, namun Sisi mengalami kesulitan pelafalan pada kata berikut.

Pelafalan konsonan [n] oleh Sisi tersebut dapat dikatakan bahwa alat wicara Sisi mengalami kesulitan dalam mengartikulasikan bunyi konsonan [n] pada kata mendung 
Kemampuan Pelafalan Bunyi Kosakata Dasar Bahasa Indonesia oleh Lutsiana Anak Tunagrahita

Ringan di SLB Negeri Patrang Kabupaten Jember (Nenes Mardiati, Asrumi, Budi Suyanto)

[monduy] yang berhubungan dengan pengaturan arus udara, sehingga mengakibatkan Sisi tidak mampu melafakannya. Pelafalan kata mendung [məndū] menjadi medun [mədUn].

\section{Pelafalan Bunyi Konsonan [p]}

Pada data pelafalan bunyi konsonan [p], Sisi mengalami kesulitan pada saat melafalkan kata garpu [garpu], untuk lebih jelasnya dapat dilihat pada uraian berikut.

\begin{tabular}{|l|l|l|}
\hline $\begin{array}{l}\text { Kosakata Bahasa } \\
\text { Indonesia }\end{array}$ & Pelafalan Sisi & $\begin{array}{l}\text { Bentuk } \\
\text { Perubahan }\end{array}$ \\
\hline $\begin{array}{l}\text { Garpu } \\
\text { [garpu }]\end{array}$ & $\begin{array}{l}\text { Gambu } \\
\text { [gambu }]\end{array}$ & $\mathrm{p}-\mathrm{b}$ \\
\hline
\end{tabular}

Kata garpu [garpu] memiliki pola silabel KVdan konsonan [p] sebagai onset. Kata garpu [garpu] memiliki dua, yaitu [gar] dan [pu]. Pada silabe kedua yaitu [pu] mengalami penggantian bunyi [p] menjadi [b], sehingga kata garpu [garpu] menjadi gambu [gambu]. Bunyi [p] dan bunyi [b] merupakan konsonan hambat letup bilabial yang terjadi bila penghambat artikulator aktifnya adalah bibir bawah dan artikulator pasifnya adalah bibir atas. Dalam pelafalannya, Sisi mengalami kekeliruan dalam letupan udara yang keluar dari rongga mulut. Bunyi yang dihasilkan seharusnya konsonan [p] keras tak bersuara namun yang dilafalkan Sisi adalah konsonan [b] lunak bersuara.

\section{Pelafalan Bunyi Konsonan [r]}

Pelafalan konsonan [r] pada silabe pertama dengan [r] sebagai onset Sisi tidak megalami kesulitan dalam melafalkannya. Sisi mengalami kesulitan dalam melafalkan konsonan [r] diantaranya yaitu terjadinya penggantian bunyi konsonan [r] menjadi [1], penggantian bunyi konsonan [r] menjadi [y], penggantian bunyi [r] menjadi [m] dan penghilangan bunyi [r], berikut uraiannya.

\begin{tabular}{|l|l|l|}
\hline $\begin{array}{l}\text { Kosakata Bahasa } \\
\text { Indonesia }\end{array}$ & Pelafalan Sisi & $\begin{array}{l}\text { Bentuk } \\
\text { Perubahan }\end{array}$ \\
\hline $\begin{array}{l}\text { Akar } \\
\text { [akar] }\end{array}$ & $\begin{array}{l}\text { Akal } \\
\text { [akal] }\end{array}$ & $\mathrm{r}-1$ \\
\hline $\begin{array}{l}\text { Jari } \\
\text { [jari] }\end{array}$ & $\begin{array}{l}\text { Jayi } \\
\text { [jayi] }\end{array}$ & $\mathrm{r}-\mathrm{y}$ \\
\hline $\begin{array}{l}\text { Garpu } \\
\text { [garpu] }\end{array}$ & $\begin{array}{l}\text { Gambu } \\
\text { [gambu] }\end{array}$ & $\mathrm{r}-\mathrm{m}$ \\
\hline $\begin{array}{l}\text { Kursi } \\
{[\text { kursi }]}\end{array}$ & $\begin{array}{l}\text { Kuti } \\
{[\text { kuti] }}\end{array}$ & $\mathrm{r}-$ hilang \\
\hline
\end{tabular}

Bunyi konsonan [r] oleh Sisi di atas dapat diuraikan bahwa penggantian bunyi [r] menjadi [1] terjadi pada silabe terakhir suatu kata dengan pola KVK dan [r] sebagai sebagai koda. Pada pelafalan bunyi [r] menjadi [y] terjadi pada silabe kedua suatu kata dengan pola KV dan KVK, posisi [r] sebagai onset. Penggantian bunyi konsonan [r] menjadi konsonan [m] hanya terjadi pada kata garpu [garpu]. Kata garpu [garpu] memiliki dua silabe, yaitu [gar] dan [pu]. Pada silabe kedua terjadi penggantian konsonan [p] menjadi [b], Sisi mengalami kekeliruan dalam letupan udara yang keluar dari rongga mulut sehingga memengaruhi bunyi sebelumnya. 
Ketidakmampuan Sisi dalam melafalkan konsonan [r] bukan hanya terjadi penggantian bunyi saja tetapi juga terjadi penghilangan bunyi, yaitu pada kata kursi [kursi] menjadi kuti [kuti]. Bunyi konsonan [r] terdapat pada silabe pertama dengan posisi sebagai koda diikuti oleh konsonan [s] yang merupakan konsonan geseran, bunyi [s] pun tidak mampu dilafalkan karena Sisi kesulitan untuk menjaga kerapatan arus udara yang mengalir di antara ujung lidah dan gusi atas dalam membentuk bunyi desis [s]. Ketidakmampuan Sisi dalam melafalkan konsonan [r] pada suatu kata disebabkan ia tidak mampu membentuk gelombang arus udara yang keluar dari paru-paru untuk menggetarkan ujung lidah.

\section{Pelafalan Bunyi Konsonan [s]}

Dari sekian kata yang dilafalkan Sisi, ada satu kata yang tidak mampu dilafalkan dengan normal yaitu kata kursi [kursi] terjadi penggantian konsonan [s] menjadi konsonan [t] pada silabe kedua. Kata kursi [kursi] menjadi kuti [kuti]. Hal ini terjadi karena Sisi tidak mampu menjaga kerapatan arus udara yang mengalir di antara ujung lidah dan gusi atas dalam membentuk bunyi desis [s].

\section{Pelafalan Bunyi Konsonan [t]}

Bunyi konsonan [t] merupakan konsonan hambat letup apiko-dental. Proses artikulasi bunyi konsonan [t] yaitu ujung lidah sebagai artikulator aktif merapat atau menyentuh gigi atas yang menjadi artikulator pasifnya. Namun, Sisi melafalkan konsonan [t] dengan tengah lidah menjadi artikulator aktif mendekati gigi atas yang merupakan artikulator pasif. Dalam pelafalan bunyi konsonan [t] Sisi tidak mengalami kesulitan dalam pelafalannya.

\section{Pelafalan Bunyi Konsonan [w]}

Bunyi konsonan [w] juga disebut dengan bunyi semi-vokal bilabial, artikulator aktifnya adalah bibir bawah dan artikulator pasifnya adalah bibir atas. Cara artikulasinya adalah langit-langit lunak dinaikkan sehingga udara tidak keluar dari rongga mulut, kemudian bibir bawah dibentangkan didekatkan pada bibir atas tetapi tidak sampai rapat. Pada pelafalan konsonan [w] Sisi tidak mengalami kesulitan, sehingga ia dapat melafalkan seperti orang nomal.

\section{Pelafalan Bunyi Konsonan [y]}

Bunyi konsonan [y] juga disebut dengan bunyi semi-vokal medio palatal, artikulator aktifnya adalah tengah lidah dan artikulator pasifnya adalah langit-langit keras. Pada pelafalan konsonan [y] Sisi tidak mengalami kesulitan, sehingga ia dapat melafalkan seperti orang nomal.

\section{Pelafalan Bunyi Konsonan [y]}

Dari data pelafalan bunyi [y] tersebut dapat dilihat bahwa hampir semua kata tidak mampu Sisi lafalkan dengan benar. Bentuk-bentuk kesulitan pelafalan bunyi konsonan [y] 
yaitu terjadi penggantian bunyi konsonan [y] menjadi konsonan [n] atau konsonan [1], dan penghilangan bunyi $[\mathrm{\eta}]$, berikut uraiannya.

\begin{tabular}{|l|l|l|}
\hline $\begin{array}{l}\text { Kosakata Bahasa } \\
\text { Indonesia }\end{array}$ & Pelafalan Sisi & $\begin{array}{l}\text { Bentuk } \\
\text { Perubahan }\end{array}$ \\
\hline $\begin{array}{l}\text { Mangkuk } \\
{[\text { mankuk] }}\end{array}$ & $\begin{array}{l}\text { makuk } \\
{[\text { makU?] }}\end{array}$ & $\mathrm{y}$-hilang \\
\hline $\begin{array}{l}\text { Bintang } \\
\text { bintan] }\end{array}$ & $\begin{array}{l}\text { bintan } \\
{[\text { bintan] }}\end{array}$ & $\mathrm{y}-\mathrm{n}$ \\
\hline $\begin{array}{l}\text { Jagung } \\
\text { [jagun] }\end{array}$ & $\begin{array}{l}\text { jakul } \\
\text { [jakUl] }\end{array}$ & $\mathrm{y}-1$ \\
\hline
\end{tabular}

Dari data terjadinya perubahan pelafalan konsonan [y] oleh Sisi di atas disebabkan Sisi kesulitan untuk menggerakkan lidah bagian belakang menyentuh langit-langit keras atau lunak dalam. Penghilangan bunyi konsonan [y] terjadi ketika diikuti dengan konsonan $[\mathrm{k}]$.

Penggantian bunyi [n] menjadi bunyi [n] terjadi apabila vokal [a], vokal [i], dan vokal $[\mathrm{u}]$ mengikuti konsonan $[\mathrm{y}]$. Namun ada beberapa kata jika vokal $[\mathrm{u}]$ mengikut konsonan [y] maka bunyi [y] berubah menjadi bunyi [1]. Hal tersebut terjadi apabila vokal $[\mathrm{u}]$ didahului oleh konsonan $[\mathrm{g}],[\mathrm{k}]$, dan $[\mathrm{p}]$.

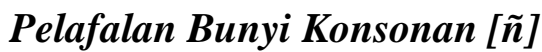

Bunyi konsonan [ñ] merupakan konsonan nasal medio-palatal. Proses artikulasi bunyi laminopalatal yaitu daun lidah sebagai artikulator aktif mengenai langit-langit keras (palatum) yang menjadi artikulator pasif. Dari data pelafalan bunyi konsonan [ñ] tersebut, Sisi mampu melafalkan konsonan [ñ] dengan pola silabe KV maupun KVK.

Berdasarkan uraian di atas dapat dikatakan bahwa kemampuan pelafalam vokal Sisi anak tunagrahita ringan pada kosakata dasar bahasa Indonesia ada yang normalmal, yakni: bunyi [a] dilafalkan [ə]; bunyi [i] dilafalkan \{i], [I] tinggi, dan [i?]; bunyi vokal [u] diucapkan $[\mathrm{u}]$ dan $[\mathrm{U}]$ tinggi atau normal; bunyi [e] diucapkan $[\mathrm{e}]$, $[\varepsilon]$, dan $[ə]$, tergolong normal; bunyi [o] dilafalkan [o] dan [0], tergolong normal; dan bunyi-bunyi diftong terjadi monodiftongisasi, yakni bunyi [ai] dilafalkan [e] dan [au] dilafalkan [o], tergolong normal. Dalam pelafalan bunyi-bunyi konsonan juga ada yang dilafalkan secara normal dan tidak normal. Pelafalan bunyi-bunyi konsonan yang tergolong normal oleh Sisi, yaitu pelafalan konsonan [c], [j], [k], [t], [w], [y], dan bunyi [ñ]; yang pelafalannya tidak normal, yakni bunyi [b] jadi [p]; bunyi [d] pada awal kata menjadi hilang; bunyi [g] jadi [k]; bunyi [h] menjadi hilang; bunyi [l] menjadi [b]; bunyi [m] menjadi hilang; bunyi [n] menjadi hilang; bunyi $[\mathrm{p}]$ menjadi $[\mathrm{b}]$; bunyi $[\mathrm{r}]$ menjadi $[\mathrm{l}],[\mathrm{y}],[\mathrm{m}]$, dan ada yang hilang; bunyi $[\mathrm{s}]$ menjadi [t]; dan bunyi [n] menjadi hilang, jadi [n], dan dapat juga jadi [1].

\section{Faktor-faktor yang Mempengaruhi Terjadinya Kesulitan Pelafalan Bunyi Bahasa}

Ketidakmampuan pelafalan bunyi-bunyi kosakata dasar bahasa Indonesia Sisi disebabkan oleh beberapa faktor. Faktor-faktor tersebut selain pengaruh dari lingkungan 
sosial juga meliputi pengaruh persepsi dan kondisi bunyi bahasa Sisi dalam melafalkan kosakata dasar bahasa Indonesia yang didasari oleh teori-teori yang sudah ada. Pengaruh persepsi pelafalan kosakata oleh Sisi bergantung pada faktor keadaan kesehatan yang dimilikinya, sedangkan kondisi bunyi bahasa yang dimaksud adalah kondisi alat ujaran serta pendengaran yang dimiliki Sisi dalam memproses bahasa. Adapun deskripsi mengenai pengaruh persepsi dan kondisi produksi bunyi bahasa Sisi dapat dipahami kembali pada uraian berikut.

\section{Persepsi Bunyi Bahasa}

Persepsi bunyi bahasa oleh Sisi dipengaruhi oleh faktor kesehatan yang kemudian merubah cara ia dalam menangkap, membedakan, dan memahami bunyi bahasa. Kesehatan merupakan hal yang sangat mempengaruhi anak tunarahita ringan dalam mempersepsi bunyi bahasa yang disebabkan oleh disfungsi atau kerusakan otak (daerah Broca dan Wernicke) dengan kecerdasan jauh di bawah rata-rata. Kerusakan pada otak tersebut mempengaruhi Sisi dalam mempersepsi bunyi bahasa, dalam hal ini juga dapat dikatakan sebagai gangguan proses komunikasi. Ada dua hal yang berkenaan dengan gangguan proses komunikasi, yaitu gangguan berbicara dan gangguan berbahasa.

Gangguan berbicara mengakibatkan Sisi mengalami kesulitan dalam mengartikulasi bunyi bahasa yang benar. Hal yang lebih serius dari gangguan berbicara yaitu gangguan berbahasa, yakni seorang anak mengalami kesulitan dalam memahami dan menggunakan kosakata. Gangguan berbahasa atau afasia terjadi karena kerusakan pada belahan otak, Sisi termasuk dalam afasia motorik transkortikal karena terganggunya hubungan antara daerah Broca dan Wernicke. Pada umumnya afasia motorik transkortikal ini merusak sebagian daerah Broca. Penderita afasia motorik transkortikal dapat mengutarakan perkataan yang singkat, dalam teori psikologi yang lain disebut juga dengan gangguan berbahasa ekspresif.

Gangguan berbahasa ekspresif yaitu anak mengalami kesulitan mengekspresikan dirinya dalam berbicara. Sisi tampak sangat ingin berkomunikasi, namun mengalami kesulitan luar biasa untuk menemukan kata-kata yang tepat. Misalnya, untuk mengatakan "punggung" sebagai jawaban atas pertanyaan "bagian yang dipegang ini namanya apa?" Sisi tidak mampu melafalkan jawabannya, setelah peneliti memberitahu bahwa itu "punggung" Sisi berusaha menirukan namun tidak mampu, sehingga ia melafalkan "pukul". Pengaruh kesehatan itu akhirnya membatasi dan merubah cara Sisi dalam mempersepsi bunyi bahasa, yang seharusnya menangkap informasi melalui visual dan auditori dapat dengan tepat tetapi Sisi menjadi tidak mampu dalam mengartikulasikan apa yang dikatakan peneliti atau lawan bicaranya.

Dari kerusakan otak tersebut akhirnya memunculkan kesulitan persepsi bunyi bahasa oleh Sisi sehingga terjadi adanya penghilangan dan perubahan bunyi bahasa pada konsonan tertentu dalam kosakata dasar bahasa Indonesia. Realitas di lapangan menunjukkan bahwa penghilangan bunyi itu terjadi karena adanya ketidakmampuan Sisi dalam melafalkan urutan bunyi yang akhirnya bunyi tersebut tidak diujarkan dan menjadi 
hilang. Apabila terjadi penggantian bunyi, itu lebih disebabkan adanya kekeliruan persepsi Sisi dalam membedakan artikulasi bunyi pada bunyi konsonan tertentu.

\section{Produksi Bunyi Bahasa}

Produksi bunyi bahasa di dalam penelitian ini berhubungan dengan kondisi dan gerak artikulasi alat wicara Sisi dalam menghasilkan bunyi bahasa. Kondisi alat wicara Sisi yaitu rongga mulut sedikit lebih kecil dari rata-rata, dan lidahnya sedikit lebih besar. Kombinasi ini membuat Sisi sering mengalami kesulitan dalam mengartikulasikan bunyibunyi konsonan tertentu di dalam kosakata dasar bahasa Indonesia, fenomena tersebut dapat dikatakan sebagai gangguan fonetik. Misalnya, bunyi [r] yang merupakan konsonan getar apiko-alveolar, terjadi bila artikulator aktif yang menyebabkan proses menggetar itu ialah ujung lidah dan artikulator pasifnya adalah ceruk gigi. Pada bunyi [r] dalam pelafalannya Sisi cenderung mengalami penggantian bunyi. Penggantian bunyi itu disebabkan karena Sisi mengalami kesulitan dalam membentuk gelombang arus udara yang keluar dari paru-paru untuk menggetarkan ujung lidah, kerusakan otak yang dialami oleh Sisi mempengaruhi fungsi kerja lidah yang mengakibatkan kesalahan persepsi dalam mengartikulasikan bunyi [r]. Bunyi [c] dan [j] yang merupakan konsonan hambat letup medio-palatal yang masing-masing mampu diartikulasikan secara tepat melalui alat wicara karena dapat dipersepsi dengan jelas oleh otak. Melalui deskripsi alat wicara dan gerak artikulasi bunyi tersebut, dapat dimengerti bahwa kemampuan Sisi anak tunagrahita ringan untuk memproduksi bunyi bahasa sangat dipengaruhi oleh kemampuan otak dan kondisi alat wicara. Pada bunyi vokal Sisi tidak mengalami kesulitan dalam melafalkannya, karena produksi bunyi vokal tidak mendapat hambatan dari alat ucap melainkan hanya bergantung oleh posisi lidah dan bentuk mulut.

\section{SIMPULAN}

Berdasarkan hasil analisis pelafalan bunyi-bunyi bahasa dalam kosakata dasar bahasa Indonesia pada anak tunagrahita ringan, dapat disimpulkan bahwa terdapat bentukbentuk kesesuaian (mampu) dan ketidaksesuaian (ketidakmampuan) Sisi dalam melafalkan bunyi-bunyi bahasa tertentu. Bentuk-bentuk kesesuaian bunyi bahasa yang dilafalkan Sisi dapat diketahui pada kemampuan Sisi dalam melafalkan bunyi vokal bahasa Indonesia. Pada bunyi diftong terdapat proses monoftongisasi yang merupakan pengaruh dari bahasa Jawa, karena orang tua Sisi merupakan orang Jawa. Pada pelafalan bunyi konsonan bahasa Indonesia terjadi kesesuaian dan ketidaksesuaian ketika Sisi melafalkannya. Kesesuaian atau kemampuan Sisi dalam melafalkan bunyi konsonan dapat dilihat pada konsonan [c], [j], [k], [t], [w], [y] dan [ñ]. Ketidakmampuan Sisi dalam melafalkan bunyi konsonan berupa penggantian dan penghilangan bunyi dalam kosakata dasar bahasa Indonesia. Penghilangan bunyi konsonan meliputi bunyi $[\mathrm{d}],[\mathrm{h}],[\mathrm{m}],[\mathrm{n}],[\mathrm{r}]$, dan [y] pada kata tertentu, sedangkan bentuk-bentuk penggantian bunyi konsonan meliputi bunyi [g] menjadi bunyi [k]; bunyi [r] menjadi bunyi [1], menjadi bunyi [y], dan menjadi bunyi [m]; bunyi [s] 
menjadi bunyi [t]; bunyi [y] menjadi bunyi [n] dan menjadi bunyi [1]; bunyi [b] menjadi bunyi [p]; bunyi [1] menjadi bunyi [b]; dan bunyi [p] menjadi bunyi [m].

Ketidakmampuan Sisi dalam melafalkan bunyi konsonan tersebut dipengaruhi oleh faktor lingkungan sosial dan faktor kesehatan. Faktor kesehatan yaitu terjadi kerusakan pada otak bahasa Sisi yang mengakibatkan Sisi mengalami gangguan proses komunikasi. Otak bahasa Sisi kurang mampu menstimulus alat wicaranya untuk memahami, membedakan, dan memproses bunyi bahasa secara tepat. Kondisi alat wicara Sisi yaitu lidahnya yang sedikit lebih besar dan tebal sehingga berdampak pada produksi bunyi-bunyi bahasa yang dihasilkannya dan mengakibatkan terjadinya gangguan fonetik.

\section{DAFTAR PUSTAKA}

Angwidya. F.A. 2017.. 2017. Pengaruh Lagu Terhadap Penguasaan Kosakata Anak Down Syndrome (Studi Kasus pada Shinta). Journal Stilistika. Volume 10, No. 2. JuliDesember 2017. hlm. 48. stilistikapbsi@gmail.com.

Chaer, A. 2003. Psikolinguistik: Kajian Teoritik. Jakarta: Rineka Cipta

Chaer, A. 2009. Fonologi Bahasa Indonesia. Jakarta: Rineka Cipta

Davison, G. C; Neale, J. M.; \& Kring, A. M. 2006. Psikologi Abnormal Edisi ke-9. Jakarta: PT Raja Grafindo Persada.

Subroto, E. 1992. Pengantar Metode Penelitian Linguistik Struktural. Surakarta: Sebelas Maret University Press.

Halgin, R.P. dan Whitbourne, S. K. 2010. Psikologi Abnomal Perspektif Klinis pada Gangguan Psikologi Edisi 6 Buku 2. JakartaSalemba Humanika.

Keraf, G. 1984. Linguistik Bandingan Historis. Jakarta: PT Gramedia

Mahsun. 2006. Metode Penelitian Bahasa. Jakarta: PT Raja Grafindo Persada.

Muryani. T. 2017. "Analisis Kesalahan Fonologis pada Anak Tunagrahita dan Implikasinya Terhadap Pembelajaran (Studi Kasus Sekolah Atas Luar Biasa C di Sekolah Luar Biasa Permata Ciranjang Kabupaten Cianjur)". Skripsi. Jakarta: UIN Syarif Hidayatullah.

Pateda, M. 1990. Aspek-aspek Psikolinguistik. Yogyakarta: Nusa Indah

Puspitasari. H.R. 2012. "Penguasaan Kosakata Bahasa Indonesia Pada Anak Tunagrahita di SDLBN C Tamanagung Kecamatan Cluring Kabupaten Banyuwangi', Skripsi. Jember: Universitas Jember.

Sudaryanto. 1993. Metode dan Aneka Teknik Analisis Bahasa. Yogyakarta: Duta Wacana University Press.

Sudaryanto. 2015. Metode dan Aneka Teknik Analisis Bahasa. Yogyakarta: Sanata Dharma University Press.

Tarigan, H. G. 1993. Pengajaran Kosakata. Bandung: Angkasa. 